\title{
Achievement and response of students at favorite junior high schools in sukabumi on trends in international mathematics and science study (timss) questions
}

\author{
Suhendar*, Ayi Wahyuni \\ Biology Education, Faculty of Teacher Training and Education, Universitas Muhammadiyah \\ Sukabumi
}

*Corresponding author: suhendar@ummi.ac.id

\section{A R T I C L E I N F O}

Article history:

Received 17 July 2018

Revised 30 September 2018

Accepted 29 October 2018

Keywords:

Domain cognitive, ecosystem concept, timss questions.

\begin{abstract}
A B S T R A C T
The research is aimed to know student achievement and teacher response on TIMSS. The research method used is descriptive. This achievement is captured the TIMSS questions in 2007 and 2011 on the ecosystem concept. The test contains 20 questions consisting of 14 essays and 6 multiple choice questions. The TIMSS questions also consist of several cognitive domains of knowing, applying and reasoning. Responses of students and teachers were collected through questionnaires and interviews. The study subjects are class VIII B 1 of School A and class VIII E School B 2 of Sukabumi in the academic year of 2015/2016. The results show that average achievement in School $A$ is in the poor category (41\%) and School B is in the fair category (56\%). The achievements based on cognitive domain, $80 \%$ for knowing the domain, $43 \%$ for applying domain and 53\% reasoning domain. Some students of School A and most of the students of School B feel interested in TIMSS problem, while the teachers think that TIMSS questions will be used if it already familiar.
\end{abstract}

(C) 2018 Universitas Negeri Jakarta. This is an open access article under the CC-BY license (https://creativecommons.org/licenses/by/4.0)

\section{INTRODUCTION}

In a global competition era, educational quality improvement program becomes the main priority for almost all countries. Basically, high-quality education produces high-quality human resources who are able to compete in the globalization era. Therefore, education becomes important in improving human resources. Quality human resources could only be achieved through quality education. Quality education is an education that able to develop the positive potential within the 
learners. Therefore, efforts in improving education quality are essential to improve Indonesia resources.

International publication of Association for the Evaluation of Educational Achievement (IEA) related to TIMSS (Trends in International Mathematics and Science Study) results in 2011 found that Indonesia is in the $40^{\text {th }}$ position of 45 countries with the average achievement of 406 . According to Rustaman (2009), the low achievement in science in TIMSS was due to, among others, the ability of Indonesian students, on average, is in the knowing ability and they are not used to solve applying and reasoning questions. The difficulty faced by Indonesian students related to those types of questions is related to their less reading strategy, and low, linear, and separated reasoning level (Rustaman, 2009). The achievement of Indonesian students in TIMSS 2011 indicates a lower average achievement than the international average.

TIMSS is an international study aiming at examining mathematics and sciences knowledge and Education Achievement). TIMSS is firstly conducted in 1995 and then it has been done on an ongoing basis for once in four years. Evaluation of education quality in the world is conducted continuously and it is expected to give information regarding the development of student achievement in a certain subject.

One of the concepts tested in the TIMSS question is ecosystem concept. Average achievement for a correct answer among students in ecosystem concept based on TIMSS 2011 data is $27.09 \%$ for Indonesian students, whereas the international average is $38 \%$ (TIMSS, 2012). Based on the data, the average achievement of Indonesian students in answering TIMSS questions in ecosystem concept is lower than those of International students.

Based on observations at several public junior high schools in Sukabumi, it was found that the TIMSS test for ecosystem material had never been given. So there is no description of how the student's ability to solve TIMSS questions. Included in the two favorite public junior high schools which are among them. The favorite school is a school in Sukabumi which has a strict selection of prospective students by applying a high passing grade. In addition, there are other criteria such as requiring achievement in extracurricular fields. Nearly $65 \%$ of elementary school graduates make these two favorite schools the first choice. Because of the quality of this good student input, the research to find out the profile of TIMSS achievements is very appropriate to be done in these two favorite schools. This research was carried out with the aim to find out information about the achievements and responses of favorite public junior high school students in Sukabumi regarding TIMSS questions on the concept of ecosystems.

\section{METHOD}

The research type was descriptive with research target of TIMSS 2007 and 2011 questions in tested ecosystem concept. Respondents were students in class VIII in two favorite public junior high schools in Sukabumi of 74 students. In the research, the first stage was selecting TIMSS 2007 and 2011 questions in ecosystem theme in timss@bc.edu. page. There were 20 questions translated into Bahasa

The questionnaire used to find out students response. Statements in the questionnaire consisted of 12 items. The questionnaire consisted of negative and positive statements. Whereas, for the teacher, the direct interview was conducted using an interview format.

Data analysis technique used was processing data obtained from the test result of questions related to the ecosystem concept of TIMSS 2007 and 2011 into a percentage. Student achievement categorized. Percentage $30 \%-39 \%$ is categorized as very poor, percentage $40 \%-55 \%$ is categorized as poor, percentage $56 \%-65 \%$ is categorized as fair, percentage $66 \%-79 \%$ is categorized as good, and percentage $80 \%-100 \%$ is categorized as excellent (Arikunto, 2013).

TIMSS questions were tested to one of the class VIII in two favorite junior high schools in Sukabumi. The selection of both schools was based on a recommendation from the Department of Education and Culture Sukabumi. The tested questions were 20 items consisted of 4 multiple choice questions with 4 (four) answer options and 16 short description questions. 


\section{RESULT AND DISCUSSION}

\section{Profile of Student Achievement in TIMSS Questions}

Overall, the total score obtained was 834 from 74 students, whereas, a maximum score of the 74 students was 1702 . The average student achievement was 50\%. The low student achievement in TIMSS questions was due to students who less familiar to the questions and they were not trained with TIMSS-like questions. It is in accordance with Oktaningrum (2014) stated that one of the causing factors was Indonesian students were poorly trained in solving contextual questions, and questions that demand reasoning, argumentation, and creativity, which are the characteristics of TIMSS questions.

The low achievement also caused by students who have not understood the point of the questions. Some questions had unfamiliar biological terms thus students had difficulty to understand, like neritic zone and intertidal zone. According to Manokore \& Williams (in Murni, 2016), the difficulty in biological concept is not only related to its abstract concept character but also the number of foreign terms. It is one of the causing factors of low student achievement.

Muhibbin (2005) stated that student achievement is influenced by, at least, three factors:

a. Internal factors (factors within the students): students' physical and spiritual condition.

b. External factors (factors outside the students): environmental condition around the students.

c. Approach to learning factors: type of student learning efforts consisted of strategies and methods used by students in subject materials learning activity.

2. The result of Student Achievement Profile in TIMSS Questions based on the Cognitive Domain

The characteristic of TIMSS questions based on the knowledge domain is that it consisted of three domains: knowing, applying and reasoning. Based on the characteristics, student achievement based on the cognitive domain is presented in the following Figure 1.

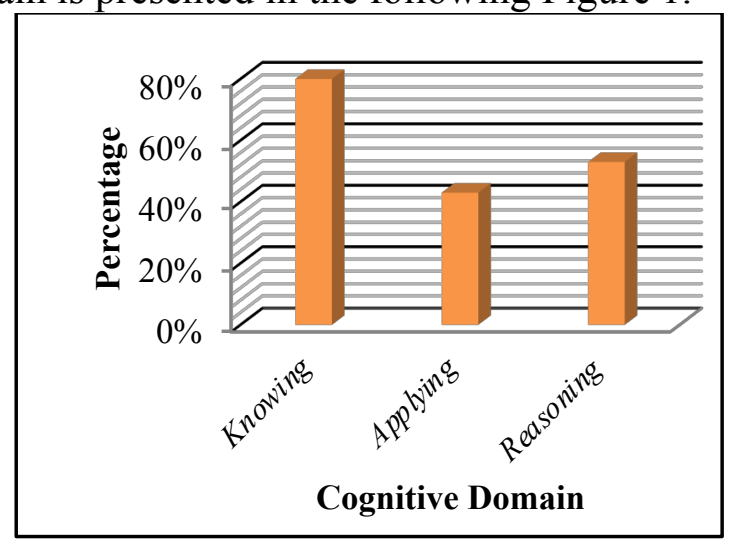

Figure 1. Average Student Achievement in TIMSS Questions on Cognitive Domain.

Data processing result produced student percentage of $80 \%$ for the cognitive domain of knowing. Knowledge aspect is a thinking ability that able to see and memorize what is learned. In teaching and learning process, the student is expected to absorb certain information and expected behavior condition in remembering the information.

According to Sudarsyah (2013), question difficulty level will follow the hierarchy of Bloom's cognitive taxonomy. Easy category question develops based on knowing and understanding cognitive ability level. Medium category question develops from applying and analyzing ability levels. Whereas, difficult category question develops from evaluation or creation ability levels.

According to Gagne's systematic (Winkel, 1987), abilities are grouped into ability in verbal information, intellectual proficiency, cognitive activity arrangement, motoric skill, and ability attitude that are produced by learning efforts but create an internal ability that should be stated and proven in an achievement. Learning achievement achieved by students is based on internal ability obtained. 
Application aspect is an ability to apply knowledge gained in teaching and learning process to face new situations in the daily life. In this level, ability can be measured using concepts, principles, theories, and methods to face problems in the daily life.

The second cognitive domain is applying. The domain obtained the result of $43 \%$. There were 7 questions in this domain of the 20 questions tested. According to Gagne's systematic (Winkel, 1987), abilities are grouped into ability in verbal information, intellectual proficiency, cognitive activity arrangement, motoric skill, and ability attitude that are produced by learning efforts but create an internal ability that should be stated and proven in an achievement. Learning achievement achieved by students is based on internal ability obtained. Application aspect is an ability to apply knowledge gained in teaching and learning process to face new situations in the daily life. In this level, ability can be measured using concept, principle, theory, and method to face problems in the daily life. The achievement result in the applying domain was lower than knowing the domain. The applying domain required students to compare, distinguish, and classify to interpret scientific information based on scientific concepts or principles. Questions in this domain were those with indicators of, for example, seawater condition, environmental condition, the relationship between rabbit population and fox. Comparison question indicators were, for example, comparing the current environmental condition to the condition if the human population in a city is increased. Students were demanded to relate their understanding to the daily life. Achievement in the domain was at a poor level. Students have not completely mastered the applying type questions.

The third domain was the reasoning. The domain had the highest level among the three domains in TIMSS questions. There were 11 questions tested in the domain. The selection was expected to help students to train their ability in the highest cognitive domain in TIMSS questions. The achievement result in reasoning domain was 53\%. The result was larger than those in applying cognitive domain. However, the achievement was considered low compared to knowing the domain. This type of question required students to involve in scientific reasoning to solve problems, develop an explanation, draw a conclusion, make a decision, and expand their knowledge to a new situation. The question indicators were, for example, the human population, the shark population, and so on. In human population indicator, students required to observe a graph indicating the change in human population, whereas in shark population, students required to give a scientific reason on the change in shark population due to the decrease in food reserve.

Student ability based on the data was at the knowledge level. However, student achievement in the reasoning level needed to be awarded. Students received 53\% in the highest level of TIMSS although it still low. Nevertheless, the level can be stated as sufficient for students who received reasoning type of question like in TIMSS for the first time. Students need more practice and to be trained regarding the reasoning type questions so their ability is improved.

\section{The result of Student Achievement Profile in TIMSS Questions based on School}

Profile of Student Achievement in TIMSS Questions in school A is different from in School B. For more details are presented in Figure 1 and Figure 2.

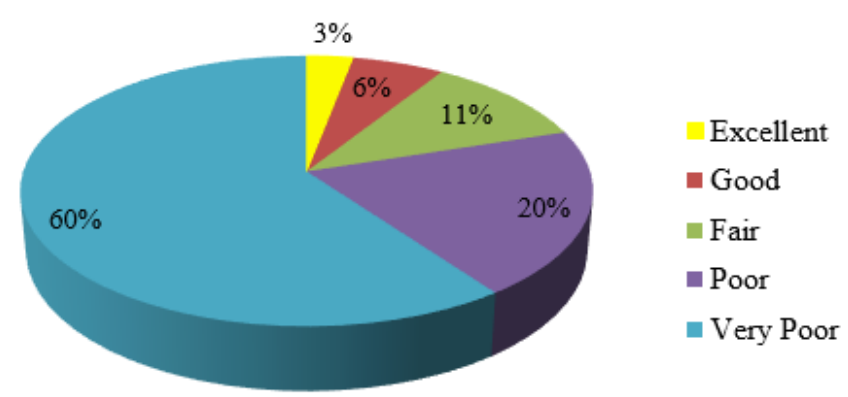

Figure 2. Diagram of Comparison of Student Achievement Category in TIMSS Questions in School A 


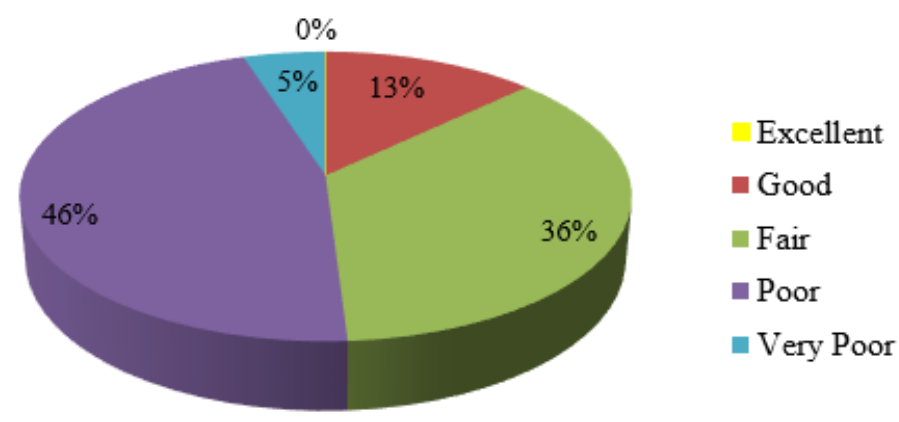

Figure 3. Diagram of Comparison of Student Achievement Category in TIMSS Questions in School B

Figure 2 is student achievement in School A in TIMSS questions tested. The figure indicates that $3 \%$ of students were in the excellent category, $6 \%$ in the good category, $11 \%$ in fair category, $20 \%$ in poor category, and $60 \%$ in the very poor category. The low student achievement was also influenced by student physical condition. Data collection in School A was conducted at noon after students completed their final exam questions. It is one of the factors causing the lack of student concentration in completing TIMSS questions.

Figure 3 is student achievement in School B. The figure indicates that $13 \%$ of students received good category, $36 \%$ in fair category, $46 \%$ in poor category, and $5 \%$ in the very poor category. Data collection in School B was conducted in the morning. Similar to School A, students in School B just completed their final exam questions. However, students in School B were relatively superior. Time played role in this condition as stated by Hakim (2005) that time has an influence on one's learning success. A student could achieve success in learning if he/she has an appropriate time to learn and able to manage time to be more efficient thus more effective learning process (Istiana \& Awaludin, 2018; Maya, et al., 2017).

Ecosystem material in the TIMSS question there is 20 topics or indicators tested. These topics are human population, food web, shark population, marine zone, marine life, environmental conditions, population, oxygen/carbon dioxide cycle, energy flow, water flow in plants, tree planting, weed removal, rabbit population level, rabbit population relationship with fox, understanding of producers, prediction of the population of the state, land use, pollution, antelope population, algae population (NCES, 2016) The lowest topic score is the topic of the marine zone, while the topic with the highest score is environmental conditions. Low scores on marine zone topics because students are not familiar with existing terms, such as neritic zones. While on the topic of environmental conditions, the majority of students get high grades because the material is close and contextual to their daily lives.

Another influence was motivation toward TIMSS questions. Students in School B tended to be more interested when explained about TIMSS questions than those students in School A. Interest in learning is influenced by physical and mental conditions (Hapsari, 2005; Ichsan \& Mulyani, 2018). Further, it can be explained that students who have health problems have no interest in learning since all their body potential is used to bear the pain. The majority of students in the research were in the middle of fasting; thus their physical condition is generally declining. Mental health also has a direct influence on the interest in learning. Hatred, the heart is broken or disappointment toward teachers will hamper the interest in learning. The disappointment was also indicated by students in School A and B since activities at school were longer due to completing the TIMSS questions.

Another factor mentioned in TIMSS result was the number of hours to study that also stated by Rahmawati (2016), low performers countries have larger total hours to study per year than top performer countries. The number of hours to study in Indonesia is 1095, whereas in Singapore is 986. It is in line with a research that adding hours to complete the questions added student's hours 
to study. The low achievement in the cognitive domain demanded reinforcement as stated by Rahmawati (2016) that Indonesian students need reinforcement in terms of ability to integrate information, draw a conclusion, generalize owned knowledge to other things.

The difference between teachers in schools A and B can also affect the results of student learning achievement. Unfortunately, in this study, there was no measurement of professional and pedagogical abilities of biology teachers in both schools.

\section{Profile of Student Response in TIMSS Questions}

Students showed interest to know about the international level question like TIMS questions although it tended to have a high difficulty level. In addition, the average of student achievement was low. Some students were able to complete the questions well. It was proven by a statement on the difficulty level where some of the students disagreed that the questions were too difficult. Students also indicated sentence understanding on the question by stating agreement that the sentences were easy to understand.

Interest means high tendency and passion or desire toward something. Interest has a significant influence on one's activity since with interest one will do something he/she's interested in (Dewi \& Ichsan, 2018; Muhibbin, 2005) . On the contrary, without interest, one is unlikely to do something. In other words, interest is the cause of someone does something he/she has interest in. Interest in learning can be defined as a fixed interest and tendency to pay attention or involve in learning activity due to the awareness of the importance or values of something learned. Interest toward TIMSS questions in School A was lower than those in School B and it influenced the achievement result. Achievement in School B was higher due to the higher interest toward TIMSS questions.

The characteristics of the TIMSS question that required students to master applying and reasoning abilities was also indicated by the students. Students stated that TIMSS questions trained their thinking ability. Reasoning cognitive domain was the highest domain in TIMSS questions and one of them required students to state reason. Students stated that TIMSS indeed made them use their reasoning ability. Some description questions needed a correct reason for a cause thus students required to state their opinion.

TIMSS questions in ecosystem theme also received a positive response. Students agreed that the chosen concept was related to the daily life that required students to link their knowledge to the correct answer. TIMSS question is intended for student scientific reasoning ability can be evaluated thus the result can be used to improve quality, especially student thinking ability.

\section{Profile of Teacher Response toward TIMSS Questions}

The result of teacher interview stated that teachers conducted an evaluation in form of giving questions at the end of the learning process, such as quizzes. However, teachers mostly conducted a question and answer process at the end of class. Nuriyah (2014) stated that in the early learning, an appraisal is conducted to determine a student's early ability (diagnostic) or students' placement in the certain study group. During the learning, appraisal activity is conducted to measure the achievement of the determined learning objectives and the result is used as a feedback on learning activities conducted (formative) after the learning activity, in a certain period, such as at the end of the semester or at the end of the certain educational level.

The questions used at the end of the learning period usually are made by the teacher. The use of international level questions is for the Olympic purpose. As stated by teachers regarding the type of questions known that they only knew Olympic type questions. Questions with high difficulty level like TIMSS questions were unfamiliar for them. Therefore, they never gave this type of questions to students. However, although without training on TIMSS questions, students were able to complete them well.

TIMSS questions are unfamiliar, especially among teachers and students in Sukabumi. Teacher response to TIMSS questions was fair by stating that follow up action is needed in the use of TIMSS questions. The use of TIMSS questions should be adjusted to the material taught. In 
addition, question depth is a consideration whether it is appropriate or not to be used by students. Teachers in School B also stated that the questions need to be used to train student during Olympic since the questions have a high difficulty level. The use of TIMSS will be started once the teachers have an understanding of them.

Understanding, applying, and reasoning aspects in cognitive ability domain as applied in TIMSS can be used to show students thinking ability profile. Of the three aspects, understanding and applying aspects are in the basic thinking ability, whereas reasoning aspect is in high-level thinking ability. Based on the description, student's thinking ability need to be trained through TIMSS-like questions.

\section{CONCLUSION}

Based on the research result and discussion on the achievement and response of students in favorite junior high schools through TIMSS questions in ecosystem concept, the following conclusions can be drawn:

1. The average student achievement in TIMSS questions in both schools was $56 \%$ for School B and $41 \%$ for School A. The achievement, according to Arikunto (2013), was within a fair category for School B and poor in School A.

2. Student achievement based on the cognitive domain from both schools was $80 \%$ for knowing the domain, $43 \%$ for applying domain, and 53\% for reasoning domain.

3. Student response to TIMSS questions tended to show interest although the questions have a high difficulty level. TIMSS questions required students to train their thinking ability and understanding toward daily life-related materials.

4. Teacher response indicates interest to use TIMSS questions in learning. The questions will be adjusted to material taught by considering their difficulty level.

\section{REFERENCES}

Arikunto, S. (2013). Prosedur Penelitian Suatu Pendekatan Praktik. Jakarta: Rineka Cipta.

Dewi, A. K., \& Ichsan, I. Z. (2018). Increasing junior high school student higher order thinking skills (hots) using q\&a methods in genetics topic. Proceeding of Biology Education, 2(1), 84-91. https://doi.org/10.21009/pbe.2-1.11

Hakim, T. (2005). Belajar Secara Efektif. Jakara: Puspa Swara.

Hapsari, S. (2005). Bimbingan dan Konseling SMA Untuk Kelas XII. PT Grasindo: Jakarta.

Ichsan, I. Z., \& Mulyani, S. W. W. (2018). Improving students' motoric skills through demonstration method in recycling plastic waste. JPBI (Jurnal Pendidikan Biologi Indonesia), 4(2), 189-194. https://doi.org/10.22219/jpbi.v4i2.5890

Istiana, R., \& Awaludin, M. T. (2018). Enhancing biology education students ability to solve problems in environmental science material through inquiri model-based lesson study. Biosfer: Jurnal Pendidikan Biologi, 11(1), 58-67. Doi: https://doi.org/10.21009/biosferjpb.11-1.6.

Maya, A. E, Huzaifah, S., \& Madang, K. (2017). Implementasi nilai pendidikan karakter pada pembelajaran biologi di sekolah menengah atas. Biosfer: Jurnal Pendidikan Biologi, 10(2), 42-48. Doi: https://doi.org/10.21009/biosferjpb.10-2.6.

Muhibbin, S. (2005). Psikologi Belajar. Jakarta: Raya Grafindo Perkasa. 
Murni, D. \& Romlah, S. (2016). Pengaruh Blended Learning Berbasis Scaffolding terhadap Hasil Belajar Mahasiswa pada Konsep Substansi Genetika. Makalah pada Seminar Nasional Pendidikan dan Saintek. Universitas Sultan Ageng Tirtayasa.

NCES. (2016). Trends in International Mathematics and Science Study (TIMSS). Retrived from: http://nces.ed.gov/timss/.

Nuriyah, N. (2014). Evaluasi pembelajaran: sebuah kajian teori. Jurnal Edueksos, 3(1), 73-86.

Rahmawati. (2016). Hasil TIMSS 2015: Diagnosa Hasil untuk Mutu Pendidikan dan Peningkatan Capaian. Makalah pada Seminar Hasil TIMSS.

Rustaman. (2009). Analisis Konten dan Capaian Sains Siswa Indonesia Dalam TIMSS (Trends in Internasional Mathematics and Science Study) Tahun 1999, 2003, dan 2007. Laporan Hasil Kajian Pusat Penilaian Pendidikan Badan Penelitian dan Pengembangan Departemen Pendidikan Nasional. Bandung: Tidak Diterbitkan.

Sudarsyah, A. (2013). Manajemen Implementasi Kurikulum: Sisi Lain Ujian Nasional. Retrived from: http://m.kompasiana.com/post/read/543693/1/sisi-lain-dari-un.html.

Winkel, W.S. (1987). Psikologi Pengajaran. Jakarta: Gramedia. 